\title{
ADULTHOOD IN TEACHERS OF HIGHER EDUCATION: DIFFERENCE IN THE MANAGEMENT OF THEIR WORK-LIFE BALANCE AND ORGANIZATIONAL COMMITMENT
}

\author{
Carla Carvalho \\ Universidade de Coimbra, Faculdade de Psicologia e Ciencias da Educação, Centro de Investigação em \\ Neuropsicologia e Intervenção Cognitivo Comportamental (CINEICC) \\ cms.carvalho@gmail.com \\ Ana Pinto \\ Universidade de Coimbra, Faculdade de Ciencias e Tecnologia, Centre of Business and Economics Research \\ (CEBER), e, Instituto Politecnico de Coimbra, Escola Superior de Educação, Nucleo de Investigação em \\ Ciencias Sociais e Humanas (NICSH) \\ Paulo Santos-Costa \\ Unidade de Investigação em Ciências da Saúde: Enfermagem (UICISA: E), Escola Superior de Enfermagem de \\ Coimbra \\ Pedro Parreira \\ Unidade de Investigação em Ciências da Saúde: Enfermagem (UICISA: E), Escola Superior de Enfermagem de \\ Coimbra
}

Recepción Artículo: 13 mayo 2021 Admisión Evaluación: 13 mayo 2021 Informe Evaluador 1: 26 mayo 2021 Informe Evaluador 2: 28 mayo 2021 Aprobación Publicación: 01 junio 2021

\begin{abstract}
This study aimed to compare the extent to which a sample of Portuguese teachers in Higher Education Institutions, divided into two groups (young adults, ages 20-39 years; and advance adults, ages 40-70 years), differed in the management of their work-life balance and organizational commitment. Data collection was conducted using the Work-Family Scale, the Organizational Commitment Scale and a sociodemographic questionnaire. Between 2012 and 2019, 652 participants were enrolled in the study. Through a multivariate analysis of variance (MANOVA, General Linear Model procedure), results suggest that young adult teachers display higher scores of family to work facilitation, while advance adult teachers evidence higher scores of normative commitment. Given the results found, recommendations for Higher Education Institutions were outlined.
\end{abstract}

Keywords: work-family relation; organizational commitment; adulthood; higher education teachers

\section{RESUMEN}

La edad adulta en los profesores de enseñanza superior: diferencia en la gestión de su equilibrio entre la vida laboral y personal y el compromiso organizativo. El objetivo de este estudio fue comparar el grado en que una muestra de profesores portugueses de Instituciones de Enseñanza Superior, divi- 


\section{ADULTHOOD IN TEACHERS OF HIGHER EDUCATION: DIFFERENCE IN THE MANAGEMENT OF THEIR WORK-LIFE BALANCE AND ORGANIZATIONAL COMMITMENT}

didos en dos grupos (adultos jóvenes, de 20 a 39 años; y adultos avanzados, de 40 a 70 años), diferían en la gestión de su equilibrio entre vida laboral y familiar y compromiso organizativo. La recolección de datos se realizó mediante la Escala Trabajo-Familia, la Escala de Compromiso Organizacional y un cuestionario sociodemográfico. Entre 2012 y 2019, 652 participantes se inscribieron en el estudio. A través de un análisis multivariado de la varianza (MANOVA, procedimiento de Modelo Lineal General), Ios resultados sugieren que los profesores adultos jóvenes muestran mayores puntuaciones de facilitación de la familia al trabajo, mientras que los profesores adultos avanzados evidencian mayores puntuaciones de compromiso normativo. Dados los resultados encontrados, se esbozan recomendaciones para las Instituciones de Educación Superior.

Palabras clave: relación trabajo-familia; compromiso organizacional; adultez; profesores de educación superior

\section{INTRODUCTION}

During their lifetime, individuals experience multiple roles at the same time, creating different expectations for each one of them. Every role has specific demands that the person must carry out successfully. These demands are (sometimes) incompatible between each other and, at some point, they create a conflict between roles. This phenomenon is explained within the theory of roles (Sarbin \& Allen, 1968), presented as role overload and role conflict. A person experiments role overload when the resources are not enough to overcome all the demands from different roles. Role conflict is referred, instead, to mutually incompatible role expectations.

One of the major examples of such phenomenon is associated with balancing work and personal life (composed of family life and personal benefit activities) (Allis \& O'Driscoll, 2008; Frone, 2003; Greenhaus \& Beutell, 1985). Personal benefit activities integrate roles that have their roots in religion (e.g., meditation, religious activities), personal development and education (e.g., private studies, personal goals) or leisure (e.g., sport, hobbies)(Allis \& O'Driscoll, 2008; Frone, 2003). These above-mentioned categories are activities that the individual does to take care of himself. These personal benefit activities generate, as an outcome, feelings of freedom, satisfaction and positive mood, promoting general well-being (Eden, 2001). Research, however, has focused more on the relationship between work and family instead of considering all these personal benefit activities, because family is presumed to be the major non-work aspect of life. However, Greenhaus and Beutell (1985) state that it is important to recognize that non-work responsibilities could influence work-related demands, affecting an individual's health and performance but also the other way around (a spillover effect). This phenomenon manifests itself in a person's mood, satisfaction, values, skills, and behaviour. Just recently, literature accepted that this effect could be both negative, when one domain negatively performs with another, or positive when the two domains are synergic. In literature, these two types of spillover are referred to as conflict (negative spillover) and facilitation (positive spillover)(Kalliath \& Brough, 2008). Normally, people experience both conflict and facilitation at the same time but at different levels. We can experience a high level of conflict but a low level of facilitation or the other way around. In both cases, we encounter an imbalance, and this is itself a stressor that can lead to bad outcomes in the affected life domain. It can influence the health and well-being, causing depression, anxiety, life distress, psychological strain (Grzywacz \& Bass, 2003), negative emotions (Greenhaus et al., 2006) or, more in general, dissatisfaction with life (Carlson \& Kacmar, 2000).

Recent studies have focused on the construct of Work-Life Balance (WLB), generally described as a continuum between conflict and facilitation from work to family and from family to work. To have full knowledge of the WLB spectrum, we need to consider both conflict and facilitation domains together, as a multi-dimensional construct. As previously analysed, work-family conflict and work-family facilitation are not mutually exclusive, but they coexist at the same time. Therefore, several studies supported the distinction between four dimensions (Frone, 2003; Stoiko et al., 2017): work to family conflict, family to work conflict (Frone et al., 1992) and work to family facilitation and family to work facilitation (Grzywacz \& Marks, 2000a; Grzywacz \& Marks, 2000b). The multi-dimensional construct of WLB can be depicted as a continuous interchange between conflict and facilitation. These two situations could manifest themselves both from the work environment to the family and the oppo- 
site, from the family surroundings to the work environment. If people observe a high level of conflict, the outcomes are negative and can lead to depression, stress, burnout and intention to leave the organization.

Intention to leave the organization is widely associated with Organizational Commitment (OC), a key concept in the study of work-related attitudes and behaviours (N. J. Allen \& Meyer, 1996). Meyer and Allen (1991, p.252), defined OC as "a psychological link between the employee and his/her organization that makes it less likely that the employee will voluntarily leave the organization". Meyer and Allen proposed a three-component model of OC based on previous research and previous theories, composed of affective commitment, continuance commitment and normative commitment (Meyer et al., 2002).

Current studies show that teacher burnout and intention to leave is a current concern in several economically developed countries educational system (Ahmad et al., 2019; Arnup \& Bowles, 2016; De Neve \& Devos, 2017; Johari et al., 2018). Although most of the studies carried address significant potential contributors to teachers' dissatisfaction, burnout and intention to leave, such as working conditions (collective responsibility, autonomy, reflective dialogue, job insecurity, and deprivatised practice), job satisfaction and demographic variables, few studies have dwell into teachers' WLB.

\section{AIM OF THE RESEARCH}

This study aimed to compare the extent to which a sample of Portuguese teachers in Higher Education Institutions (HEls), divided into two groups (young adults, ranging from 20 and 39 years; and advance adults, ranging from 40 and 70 years), differed in the management of their WLB and organizational commitment.

\section{SAMPLE}

Between 2012 and 2019, 652 teachers from public and private HEls in Continental Portugal and Islands were enrolled in the study. The sample is composed of 320 men (49.1\%) and 312 women (47.9\%), while 20 participants did not express their gender (3.1\%). On average, the participants were 42.76 years of age $( \pm 9.42 ; 22-70)$. Most of the participants' marital status was married (58.9\%), followed by single (22.4\%), divorced ( $8.4 \%)$, other (4.3\%) and separated (2.3\%). Twenty-one participants (3.2\%) did not express their marital status. The participants had from 0 to 5 children $(M=1,22, S D=1,06)$. Most of the participants taught in a public university $(77 \%)$ while $19.3 \%$ taught in a private university (3.7\% did not disclose this information). Seniority in the university is between 2 and 529 months $(M=154,43, S D=102,88)$.

This study covers almost entirely the country of Portugal, although a higher number of participants were recruited in the districts of Coimbra (34.7\%), followed by Lisbon area (20\%) and Castelo Branco area (12.1\%).

\section{METHOD}

\section{Instruments}

The following measurement instruments were used to perform the present study:

1. The Work-Family Scale (in Portuguese, Escala de Trabalho e Família)(Alegre et al., 2019). The WorkFamily scale comprises 25 items that sustain four major subscales: Work to Family Conflict; Family to Work Conflict; Family to Work Facilitation and Work to Family Facilitation. Each item of the Work-Family scale is scored in a four-point Likert scale, ranging between 1 (Rarely) and 4 (Most of the times).

2. The Organizational Commitment Scale (Meyer \& Allen, 1991) was adapted to European Portuguese by Carvalho and associates (2009). The scale is composed of 19 items that sustain three major subscales: Affective Commitment; Calculative Commitment and Normative Commitment. Each item of the scale is scored in a sevenpoint Likert scale ranging from 1 (Totally disagree) and 7 (Totally agree).

3. A sociodemographic questionnaire, with questions about sex, age, marital status, number of children, literacy and data concerning the professional situation.

For the validation of the constructs, the Work-Family and Organizational Commitment scales were submitted to confirmatory factor analysis using the statistical program AMOS 25.0. Outliers were analysed according to 


\section{ADULTHOOD IN TEACHERS OF HIGHER EDUCATION: DIFFERENCE IN THE MANAGEMENT OF THEIR WORK-LIFE BALANCE AND ORGANIZATIONAL COMMITMENT}

Mahalanobis squared distance and no relevant values were found (Joreskog \& Sorbom, 1982). The normality of the variables was assessed by the coefficients of skewness (Sk) and kurtosis (Ku). The goodness of fit was analysed by the indexes of NFI (Normed of fit index; good fit >.80; Schumacker \& Lomax, 2012), SRMR (Standardized Root Mean Square Residual; appropriate fit <.08; Brown, 2006), TLI (Tucker-Lewis Index - TLI; appropriate fit > .90; Brown, 2006), CFI (Comparative fit index; good fit > .90; Bentler \& Weeks, 1980, RMSEA (Root Mean Square Error of Approximation; good fit <.05; Schumacker \& Lomax, 2012), and $X^{2}$ ( $p>$.05, but irrelevant if N > 500; (Bentler \& Weeks, 1980; Schumacker \& Lomax, 2012). The fit of the model was improved by modification indices (Ml; Bollen, 1989), leading to a correlation of the residual variability between variables with $\mathrm{Ml}>90, \mathrm{p}<.001$.

The improvement of the model fit was assessed by the modification indices ( $\mathrm{Ml}$; [38]). An analysis of the MI was carried by their statistical significance ( $<0.05$ ), as proposed by Arbuckle (2013). All parameters with MI higher than $11(p<.001)$ were modified (Marôco, 2010). Reliability was calculated by Cronbach's Alpha. Reliability coefficients higher than .70 were considered acceptable for convergence and reliability (Hair et al., 2010). Generally, a value of .80 or higher was taken as a good reliability indicator. After this process, the WorkFamily Scale (Model 1) and Organizational Commitment Scale (Model 2) showed a good fit (Table 1).

Table 1. Fit statistics of Work-Family Scale and Organizational Commitment

\begin{tabular}{lllllll}
\hline $\begin{array}{l}\text { Model } \\
\text { NFI }\end{array}$ & & TLI & CFI & $\chi 2 /$ df & RMSEA & RMSEA 90\% CI \\
\hline 1 & .895 & .913 & .923 & $\begin{array}{l}3.44^{*} \\
(\mathrm{df}=113)\end{array}$ & .061 & $.057-.066^{*}$ \\
\hline 2 & .830 & .814 & .851 & $\begin{array}{l}6.77^{*} \\
(\mathrm{df}=109)\end{array}$ & .094 & $.088-.100^{*}$ \\
\hline
\end{tabular}

NFI: normed fit index; CFI: comparative fit index; 2: chi-square, df: degrees of freedom; PNFI: parsimony normed fit index; SRMR: standardized root mean square residual; RMSEA: root mean square error of approximation; Cl: confidence interval; * $p<.05$

Cronbach's alphas were considered good in every Work-Family Scale dimension. The values were above .80 in the Work to Family Conflict dimension ( $=.92$ ) and the Family to Work Conflict dimension ( $=.82)$. Regarding the Work-Family Facilitation subscale, Cronbach's Alpha was good in both the Work to Family Facilitation ( = .81 ) and the Family to Work Facilitation dimension $(=.85)$. Regarding the Organizational Commitment Scale, Cronbach's Alpha was good in the Affective Commitment $(=.85)$ and Normative Commitment $(=.86)$ subscales, while the values for the Calculative Commitment $(=.76)$ subscale were deemed acceptable.

\section{Formal and ethical procedures}

The voluntary, informed and anonymous nature of the participation was guaranteed throughout the study. Data privacy and safety were also assured. This study was approved by the Ethics and Deontology Committee of Psychological Research by the Faculty of Psychology and Educational Sciences of the University of Coimbra on November 19 of 2015.

\section{Data Analysis}

Descriptive statistics and an intercorrelation matrix were performed. A multivariate analysis of variance (MANOVA, General Linear Model procedure) was conducted according to Field's assumptions (2004). Additionally, we also followed the assumption of absence of multicollinearity (Mayers, 2013). The assumptions 
of independence of observations and randomness of the sample were guaranteed when data were collected. Statistical analysis was performed using the SPSS Statistics program (version 25, IBM SPSS, New York).

\section{RESULTS}

To compare the extent to which the two groups (young adult teachers versus advanced adult teachers) differed in the management of their WLB and OC, a multivariate analysis of variance (MANOVA) was performed. The mean scores obtained in subscales of the Work-Family Scale and Organizational Commitment Scale were considered as the dependent variables. The presence of multivariate normality was assessed by the Shapiro-Wilk test (Field, 2006) and visually through histograms, Q-Q plots and box plots.

The results indicated that the Work-Family and Organizational Commitment indexes showed non-normal distributions $(p<.05)$ for all factors. The Work-Family Scale's covariance matrix was not homogeneous, Bartlett's sphericity test [ $2(9)=654.54, p<.000]$, and the Levene's test for the homogeneity of residual variances pointed to non-significant values in all variables, $F(1,622)$ from .14 to $3.2, p>.053$. Concerning the Organizational Commitment Scale, the covariance matrix was also not homogeneous, Bartlett's sphericity test [ $2(5)=291.81$, $p<.000]$, and Levene's test pointed to non-significant values in all variables, $F(1,587)$ from .01 to 1.8, $p>.176$. The assumption of homogeneity of covariance matrices was assessed using, as a primordial basis, the results in Bartlett's sphericity test, since according to authors such as Field (2006), the Box M test should be avoided when multivariate normality does not occur. The correlations between the dependent variables are presented in Table 2. All variables presented values below -.40 and .90, informing the absence of multicollinearity (Mayers, 2013).

Table 2. Pearson's intercorrelation matrix between the constituent factors of the Work-Family Scale and the factors of the Organizational Commitment Scale.

\begin{tabular}{lllllll}
\hline Dimensions & 12 & 3 & 4 & 5 & 6 & 7 \\
\hline Work to Family Conflict (1) & $1.279^{* *}-.065$ & $-514^{* *} .095^{*}$ & .004 & $.100^{*}$ \\
Family to Work Conflict (2) & 1 & $-.135^{* *}-.058$ & -.017 & .006 & .064 \\
Work to Family Facilitation (3) & 1 & $.321^{* *} .111^{* *}-.074$ & -.001 \\
Family to Work Facilitation (4) & & 1 & .0 .37 & -.005 & -.057 \\
Affective Commitment (5) & & & 1 & $.010^{*} .239^{* *}$ \\
Normative Commitment (6) & & & & 1 & $.235^{* *}$ \\
Calculative Commitment (7) & & & & & 1 \\
\hline$* \mathrm{p}<.05 ; * * \mathrm{p}<.01$ & & & & &
\end{tabular}

There is a significant multivariate effect of the age groups on the set of dependent variables both for the mean scores of the factors of the Work-Family scale [ de Wilk $=.984, F(4,619)=2.542, p=.039$ ], with a magnitude of the experimental effect of $2=.016(1.6 \%)$, and of the Organizational Commitment Scale [ de Wilk $=.987$, $F(3,585)=2.655, p=.048)]$, with a magnitude of the experimental effect of $2=.013(1.3 \%)]$. The Wilk Lambda test was chosen because the groups of the independent variable have different sizes, and the Pillai's trace is sensitive to the presence of covariance heterogeneity (Field, 2006; Mayers, 2013), which is verified. Table 3 presents the mean scores $(M)$ and the standard deviations $(S D)$ of the measures under study, as well as the results from the univariate tests (one-way ANOVA). 
Table 3. Average scores and standard deviations of the Work-Family and Organizational Commitment scales according to age groups: Univariate tests $F$ and magnitude of the experimental effects (2)

\begin{tabular}{llll}
\hline $\begin{array}{l}\text { Young } \\
\text { Adult } \\
\text { Teachers } \\
(n=234)\end{array}$ & $\begin{array}{l}\text { Advanced } \\
\text { Adult } \\
\text { Teachers } \\
(n=355)\end{array}$ & $\begin{array}{l}\mathbf{F} \\
(1,622)\end{array}$ & $\boldsymbol{\eta}^{2}$ \\
& $(1,587)$
\end{tabular}

$\begin{array}{lllllll}\text { Work to Family Conflict } & 2.19 & .76 & 2.18 & .79 & .06 & .000 \\ \text { Family to Work Conflict } & 1.31 & .37 & 1.32 & .40 & .07 & .000 \\ \text { Work to Family Facilitation } 3.50 & .30 & 3.34 & .33 & 2.54 & .004 \\ \text { Family to Work Facilitation } 2.34 & .65 & 2.25 & .63 & 8.59 * * & .014\end{array}$

$\begin{array}{lllllll}\text { Affective Commitment } & 3.78 & .59 & 3.82 & .61 & .72 & .001 \\ \text { Normative Commitment } & 4.02 & .97 & 4.17 & 1.05 & 6.49 * * & .005 \\ \text { Calculative Commitment } & 4.26 & 1.11 & 4.50 & 1.13 & 3.09 & .011\end{array}$

$* \mathrm{p}<.05 ; * * \mathrm{p}<.01$

Findings suggest a statistically significant difference between young adult teachers (20-39 years) and advanced adult teachers (40-70 years) in two particular aspects: i) in the Family to Work Facilitation, which is superior in young adult teachers $(M=2.34)$ when compared to their older peers $(M=2.25)$; and ii) in the normative commitment, which is superior in advanced adult teachers $(M=4.17)$ when compared to their younger colleagues $(M=4.02)$.

\section{DISCUSSION}

Our findings suggest that young adult teachers display higher levels of Family to Work facilitation. Existing evidence leads to the conclusion that individual traits can enhance the sense of facilitation between roles. In a study based on the BigFive Questionnaire (Julie Holliday Wayne et al., 2004), it was found that extroversion is correlated with higher levels of facilitation between roles, with openness emerging as a predictor of Work to Family facilitation. Consciousness and agreeability are traits connected to Family to Work facilitation, while neuroticism leads to lower levels of facilitation and increases conflict (Julie Holliday Wayne et al., 2004). In another study, Sumer and Knight (2001) found out how different types of attachment can predict the positive or negative level of spillover between roles. Secure attachment was identified as a predictor of positive bidirectional spillover between work and family roles. Also, individual coping strategies could enhance work-family facilitation.

Wayne, Randel and Stevens (2003) studied if a family-supportive work culture could predict work-to-family facilitation. The result was positive. The authors found out that advanced planning, seeking support, goal setting and positive thinking were all related to family-to-work facilitation while coping and planning strategies predicted work-to-family facilitation. In addition to individual characteristics, family characteristics (e.g., age and number of children, family climate, family support system, family involvement) could predict facilitation (Grzywacz \& Marks, 2000; Wayne et al., 2003).

Evidence suggests that an individual's working hours can significantly and positively foretell work-to-family facilitation (Grzywacz \& Marks, 2000a; Grzywacz \& Marks, 2000b; Voydanoff, 2004). The accumulation of different roles, or increase in responsibilities, leads to a sense of gratification and good outcomes. Presence and commitment in nonwork-related domains could improve satisfaction and energy, offering the worker more energy to 
cope with work-related issues (Ruderman et al., 2002). Active participation in non-work domains could predict an experience of facilitation at work (Allis \& O'Driscoll, 2008; Kirchmeyer, 1995). Thus, young adult teachers may potentially find easier ways to balance their work-to-family/family-to-work roles, to relax, to "disconnect" from work-related pressure and, at the same time, use strategies that effectively promote a harmonious change of roles that can lead to a sense of well-being and quality of life.

On the other hand, our findings also support that advanced adult teachers evidence higher levels of normative commitment to their HEls, referring to a psychological obligation that employees feel towards the organization. This obligation stems from the fact that employees recognize the cost - in terms of money, time and energy spent - faced by the organization during their recurrent training. This rationale leads to a sense of loyalty to the organization, and employees tend to work hard accordingly with the organizational values (Al Momani, 2017). Throughout their vast career, teachers may experience benefits such as better salaries, opportunities, and peer recognition, which is associated with the development of a strong psychological link with their HEl. Given that young adult teachers do not experience the same benefits and personal growth in the early stages of their careers, it is expected that their older peers display higher levels of normative commitment.

\section{Implications for HEls}

According to Kalliath and Brough (2008), to achieve a balance between work and family roles, every individual must spend personal resources such as time, commitment and energy. Work demands can pose a challenge to family responsibilities (Voydanoff, 1988, 2005). Therefore, organizations such as the HEls must focus their attention to the personal life of their teachers and other employees, to implement human resources practices that promote and support work and family facilitation (Allen, 2001; Chambel \& Santos, 2009). Broockwood, Hammer, and Neal (2003) suggest that positive family-to-work spillover might increase if the organization establishes programs that support parenting efforts such as parenting classes, daycare and flexible scheduling. These examples of good practices increase the level of satisfaction among workers. Additionally, Barnett, Marshall and Sayer (1992) indicate that that women who find their work challenging but are rewarded for achieving their goals will experience less psychological distress and have better relationships with their children. These strategies foster a competitive background that also encourages the balance between family and work (Allen, 2001), increasing the level of satisfaction among employees (Brockwood et al., 2003; Chambel \& Santos, 2009). Likewise, such strategies strengthen the sense of organizational commitment since the workers recognize the organization's contributions to the balance of their family life. When employees feel that their employer cares about their personal lives and facilitates the interchange between work and family roles, their levels of satisfaction and organizational commitment increase (Wayne et al., 2003).

Based on Seiber's (1974) theory of role accumulation, Greenhaus and Powell (2006) presented the idea of work-family enrichment, which represents the extent to which positive experiences in one role improve the quality of life associated with the other (Rastogi \& Chaudhary, 2018). In the spillover theory, for example, it is assumed that emotions and behaviour in one sphere can be carried over to the other sphere (Staines, 1980). Positive spillover refers to how the participation in one life domain, like work and family, can become easier because of the skills, experiences, and opportunities gained by their participation in another domain (Grzywacz \& Bass, 2003). Other non-work activities, such as family, involvement with the community and leisure, are historically related to the decrease in the time spent working and considered as a bad modus vivendi (Marks \& MacDermid, 1996). Contrary to this line of thought, other studies have shown that the existence of different roles in a person's life had been protecting people from the effects of negative experiences in other roles (Barnett \& Hyde, 2001). Instead of reducing the person's energy for working and decreasing productivity, an individual's commitment with other life roles it may provide more satisfaction and energy for work (Ruderman et al., 2002). Empirical evidence shows that vacations and other periods of rest and leisure results in a decrease of job stress and role-induced burnout (Etzion et al., 1998; Westman \& Etzion, 2001), increasing life satisfaction (Lounsbury \& Hoopes, 1986). Thus, recurrent leave periods throughout the school year may relieve teachers from work-related negative experiences 


\section{ADULTHOOD IN TEACHERS OF HIGHER EDUCATION: DIFFERENCE IN THE MANAGEMENT OF THEIR WORK-LIFE BALANCE AND ORGANIZATIONAL COMMITMENT}

(Sonnentag, 2003), which can likely impact their productivity and intention to stay within the HEls, but also positively impact their personal and family lives.

\section{CONCLUSIONS}

Our findings suggest that young adult teachers display higher scores of family to work facilitation, which may be explained by their ability to find and implement strategies that mitigate the clash between the demands of each role. Given their extensive experience and opportunities to progress their career, advanced adult teachers displayed higher scores of normative commitments to their HEls than young adult teachers. Based on such findings, several organizational strategies were proposed to foster the facilitation between work and family roles amongst teachers.

\section{BIBLIOGRAPHIC REFERENCES}

Ahmad, S., Batool, A., \& Hussain Ch., A. (2019). Work-Related Attitudes of Teachers and Intention to Leave Teaching Profession. Research on Humanities and Social Sciences, 9(23), 52-59.

Al Momani, H. M. (2017). The Mediating Effect of Organizational Commitment on the Relationship between Worklife Balance and Intention to Leave: Evidence from Working Women in Jordan. International Business Research, 10(6), 164. https://doi.org/10.5539/ibr.v10n6p164

Alegre, M. I., Carvalho, C., Mónico, L., \& Parreira, P. (2019). Work-family conflict and facilitation: A study with Burnout profiles of Portuguese professors. Psicologia Educação e Cultura, 23(1), 128-151.

Allen, N. J., \& Meyer, J. P. (1996). Affective, Continuance, and Normative Commitment to the Organization: An Examination of Construct Validity. Journal of Vocational Behavior, 49(3), 252-276. https://doi.org/10.1006/jvbe.1996.0043

Allen, T. D. (2001). Family-Supportive Work Environments: The Role of Organizational Perceptions. Journal of Vocational Behavior, 58(3), 414-435. https://doi.org/10.1006/jvbe.2000.1774

Allis, P., \& O'Driscoll, M. (2008). Positive effects of nonwork to work facilitation on well being in work, family and personal domains. Journal of Managerial Psychology, 23(3), 273-291. https://doi.org/10.1108/02683940810861383

Arbuckle, J. L. (2013). Amos 22 user's guide. SPSS Inc.

Arnup, J., \& Bowles, T. (2016). Should I stay or should I go? Resilience as a protective factor for teachers' intention to leave the teaching profession. Australian Journal of Education, 60(3), 229-244. https://doi.org/10.1177/0004944116667620

Barnett, R. C., \& Hyde, J. S. (2001). Women, men, work, and family. An expansionist theory. The American Psychologist, 56(10), 781-796. https://doi.org/10.1037//0003-066x.56.10.781

Barnett, R. C., Marshall, N. L., \& Sayer, A. (1992). Positive-spillover effects from job to home: A closer look. Women \& Health, 19(2-3), 13-41. https://doi.org/10.1300/J013v19n02_02

Bentler, P., \& Weeks, G. (1980). Linear structural equations with latent variables. Psychometria, 45, 289-308.

Bollen, K. A. (1989). Structural equations with latent variables. Wiley.

Brockwood, K. J., Hammer, L. B., \& Neal, M. B. (2003). An examination of positive work-family facilitation among dual-earner couples in the sandwiched generation. 18th annual conferences of the SIOP, Orlando, FL.

Brown, T. (2006). Confirmatory Factor Analysis for Applied Research. The Gilford Press.

Carlson, D. S., \& Kacmar, K. M. (2000). Work-Family Conflict in the Organization: Do Life Role Values make a Difference? Journal of Management, 26(5), 1031-1054. https://doi.org/10.1177/014920630002600502

Chambel, M. J., \& Santos, M. V. dos. (2009). Práticas de conciliação e satisfação no trabalho: Mediação da facilitação do trabalho na família. Estudos de Psicologia (Campinas), 26(3), 275-286. https://doi.org/10.1590/S0103-166X2009000300001 
De Neve, D., \& Devos, G. (2017). Psychological states and working conditions buffer beginning teachers' intention to leave the job. European Journal of Teacher Education, 40(1), 6-27. https://doi.org/10.1080/02619768.2016.1246530

Eden, D. (2001). Vacation and other respites: Studying stress on and off the job. In Well-being in Organizations (Cooper CL and Robertson IT (ed), pp. 305-330). Wiley.

Etzion, D., Eden, D., \& Lapidot, Y. (1998). Relief from job stressors and burnout: Reserve service as a respite. The Journal of Applied Psychology, 83(4), 577-585. https://doi.org/10.1037/0021-9010.83.4.577

Field, A. (2004). Discovering statistics using SPSS for Windows. Sage Publication.

Field, A. (2006). Discovering Statistics Using SPSS. Sage Publications.

Frone, M. R. (2003). Work-family balance. In Handbook of occupational health psychology (J. C. Quick\&L. E. Tetrick (Eds.), pp. 143-162). American Psychological Association. https://doi.org/10.1037/10474-007

Frone, M. R., Russell, M., \& Cooper, M. L. (1992). Antecedents and outcomes of work-family conflict: Testing a model of the work-family interface. The Journal of Applied Psychology, 77(1), 65-78. https://doi.org/10.1037/0021-9010.77.1.65

Greenhaus, J., Allen, T., \& Spector, P. (2006). Health consequences of work-family conflict: The dark side of the w-f interface. In Employee health, coping and methodologies (P Perrewé and D Ganster (ed), pp. 61-98). Elsevier Science/JAI Press.

Greenhaus, J. H., \& Beutell, N. J. (1985). Sources of Conflict between Work and Family Roles. The Academy of Management Review, 10(1), 76. https://doi.org/10.2307/258214

Grzywacz, J. G., \& Marks, N. F. (2000). Reconceptualizing the work-family interface: An ecological perspective on the correlates of positive and negative spillover between work and family. Journal of Occupational Health Psychology, 5(1), 111-126. https://doi.org/10.1037//1076-8998.5.1.111

Grzywacz, Joseph G., \& Bass, B. L. (2003). Work, Family, and Mental Health: Testing Different Models of WorkFamily Fit. Journal of Marriage and Family, 65(1), 248-261. https://doi.org/10.1111/j.17413737.2003.00248.x

Grzywacz, Joseph G., \& Marks, N. F. (2000). Family, Work, Work-Family Spillover, and Problem Drinking during Midlife. Journal of Marriage and Family, 62(2), 336-348.

Hair, J. F., Black, W. C., Babin, B. J., \& Anderson, R. E. (2010). Multivariate data analysis (7th ed.). Prentice Hall.

Johari, J., Yean Tan, F., \& Tjik Zulkarnain, Z. I. (2018). Autonomy, workload, work-life balance and job performance among teachers. International Journal of Educational Management, 32(1), 107-120. https://doi.org/10.1108/JJEM-10-2016-0226

Joreskog, K. G., \& Sorbom, D. (1982). Recent Developments in Structural Equation Modeling. Journal of Marketing Research, 19(4), 404. https://doi.org/10.2307/3151714

Kalliath, T., \& Brough, P. (2008). Work-life balance: A review of the meaning of the balance construct. Journal of Management \& Organization, 14(3), 323-327. https://doi.org/10.5172/jmo.837.14.3.323

Kirchmeyer, C. (1995). Managing the Work-Nonwork Boundary: An Assessment of Organizational Responses. Human Relations, 48, 515 - 536., 48, 515-536.

Lounsbury, J. W., \& Hoopes, L. L. (1986). A vacation from work: Chances in work and nonwork outcomes. JAP, 71, 392-401.

Marks, S. R., \& MacDermid, S. M. (1996). Multiple Roles and the Self: A Theory of Role Balance. Journal of Marriage and the Family, 58(2), 417. https://doi.org/10.2307/353506

Marôco, J. (2010). Análise de Equações Estruturais: Fundamentos teóricos, software \& aplicações. Report Number.

Mayers, A. (2013). Introduction to Statistics and SPSS in Psychology. Pearson Education Limited.

Meyer, J. P., \& Allen, N. J. (1991). A three-component conceptualization of organizational commitment. Human Resource Management Review, 1(1), 61-89. https://doi.org/10.1016/1053-4822(91)90011-Z 
Meyer, J. P., Stanley, D. J., Herscovitch, L., \& Topolnytsky, L. (2002). Affective, Continuance, and Normative Commitment to the Organization: A Meta-analysis of Antecedents, Correlates, and Consequences. Journal of Vocational Behavior, 61(1), 20-52. https://doi.org/10.1006/jvbe.2001.1842

Rastogi, M., \& Chaudhary, R. (2018). Job crafting and work-family enrichment: The role of positive intrinsic work engagement. Personnel Review, 47(3), 651-674. https://doi.org/10.1108/PR-03-2017-0065

Ruderman, M. N., Ohlott, P. J., Panzer, K., \& King, S. N. (2002). BENEFITS OF MULTIPLE ROLES FOR MANAGERIAL WOMEN. Academy of Management Journal, 45(2), 369-386. https://doi.org/10.2307/3069352

Sarbin, T. R., \& Allen, V. L. (1968). Role Theory. In Handbook of Social Psychology (Gardner, L., Elliot, A. (ed), pp. 488-567). Addison-Wesley Publishing Company.

Schumacker, R. E., \& Lomax, R. G. (2012). A Beginner's Guide to Structural Equation Modeling. Routledge Academic.

Sieber, S. D. (1974). Toward a Theory of Role Accumulation. American Sociological Review, 39(4), 567. https://doi.org/10.2307/2094422

Sonnentag, S. (2003). Recovery, work engagement, and proactive behavior: A new look at the interface between nonwork and work. Journal of Applied Psychology, 88(3), 518-528. https://doi.org/10.1037/00219010.88.3.518

Staines, G. L. (1980). Spillover Versus Compensation: A Review of the Literature on the Relationship Between Work and Nonwork. Human Relations, 33(2), 111-129. https://doi.org/10.1177/001872678003300203

Stoiko, R. R., Strough, J., \& Turiano, N. A. (2017). Understanding "His and Her" Work-Family Conflict and Facilitation. Current Psychology, 36(3), 453-467. https://doi.org/10.1007/s12144-016-9434-2

Sumer, H. C., \& Knight, P. A. (2001). How do people with different attachment styles balance work and family? A personality perspective on work-family linkage. Journal of Applied Psychology, 86(4), 653-663. https://doi.org/10.1037/0021-9010.86.4.653

Voydanoff, P. (1988). Work Role Characteristics, Family Structure Demands, and Work/Family Conflict. Journal of Marriage and the Family, 50(3), 749. https://doi.org/10.2307/352644

Voydanoff, P. (2004). The Effects of Work Demands and Resources on Work-to-Family Conflict and Facilitation. Journal of Marriage and Family, 66(2), 398-412.

Voydanoff, P. (2005). Consequences of boundary-spanning demands and resources for work-to-family conflict and perceived stress. Journal of Occupational Health Psychology, 10(4), 491-503. https://doi.org/10.1037/1076-8998.10.4.491

Wayne, J.H., Randel, A. E., \& Stevens, J. (2003). Individual, work, and family correlates of work-family facilitation. 18th annual conferences of the SIOP, Orlando, FL.

Wayne, Julie Holliday, Musisca, N., \& Fleeson, W. (2004). Considering the role of personality in the work-family experience: Relationships of the big five to work-family conflict and facilitation. Journal of Vocational Behavior, 64(1), 108-130. https://doi.org/10.1016/S0001-8791(03)00035-6

Westman, M., \& Etzion, D. (2001). The impact of vacation and job stress on burnout and absenteeism. Psychology \& Health, 16(5), 595-606. https://doi.org/10.1080/08870440108405529 